\title{
Isolation of gene conferring salt tolerance from halophilic bacteria of Lunsu, Himachal Pradesh, India
}

\author{
Sonika Gupta, Parul Sharma, Kamal Dev and Anuradha Sourirajan * (D)
}

\begin{abstract}
Background: Halophiles offer an attractive source of genes conferring salt tolerance. Halobacillus trueperi SS1 strain of Lunsu, Himachal Pradesh, India, a strict halophile, was exploited to isolate and clone the genes for salt tolerance. The genomic library of BamH1 digest of $\mathrm{H}$. trueperi SS1 was constructed in pUC19, and recombinants were screened for salt tolerance on an LB medium containing ampicillin $(100 \mu \mathrm{g} / \mathrm{ml})$ and $\mathrm{NaCl}(0$ to $1.5 \mathrm{M})$.

Results: One recombinant clone named as salt-tolerant clone (STC) conferred salt tolerance to host Escherichia coli/ $\mathrm{DH} 5 \mathrm{a}$, which showed growth in the LB medium supplemented with ampicillin and $1.2 \mathrm{M} \mathrm{NaCl}$. Restriction digestion and PCR analysis revealed the presence of an insert of approximately $2000 \mathrm{bp}$ in the STC. DNA sequencing of the 2$\mathrm{kb}$ insert on both strands yielded a sequence of 2301 nucleotides. Protein BLAST analysis of 2301-bp sequence of $H$. trueperi SS1 present in STC showed 97\% identity to multidrug transport ATP binding/permease protein of Halobacillus karajensis. The insert contained in STC was subcloned into pGEX4T2 vector, and the recombinant clone STC/PGEX4T2 conferred salt tolerance to the bacterial host E. coli.

Conclusions: The present study led to the isolation of salt tolerance gene encoding a putative multidrug transport ATP binding/permease protein from H. trueperi SS1. The salt tolerance gene can be subcloned for transferring salt tolerance traits into agricultural crop plants for cultivation in saline and coastal lands.
\end{abstract}

Keywords: Halobacillus trueperi, Lunsu, Salt tolerance clone, Permease, Multidrug transport, Recombinant, pUC19, pGEX4T2

\section{Background}

Earth is a salty planet, as most of its water is present in oceans and seas. This salinity feature has affected and continues to affect the land on which crops are or might be grown $[1,2]$. Salinity is a major threat to food production and supply, because it limits crop yield and restricts the use of land [2].

Owing to their ability to survive in hyper-saline conditions, halophilic microbes serve as an attractive source for salt tolerance genes. Halophilic microorganisms have been explored for their application in agriculture, wherein conventional agricultural crops can be made

\footnotetext{
*Correspondence: asourirajan@gmail.com

Faculty of Applied Sciences and Biotechnology, Shoolini University, Bajhol, PO Sultanpur, District Solan, Himachal Pradesh 173229, India
}

more halotolerant by gene transfer from naturally halotolerant/halophilic microbes. Efforts are being made globally to isolate genes from microbes and plants and employ them for genetic engineering of salt tolerance in crops. Various genes responsible for providing salt tolerance and the ability to grow at elevated salt concentration have been identified from different bacteria [3], including the genes involved in synthesis and uptake of various compatible solutes [4]. These genes are important candidates for the generation of salt-tolerant recombinant microbial strains and transgenic plants $[5,6]$. Two such salt tolerance genes were reported from a pond water metagenomic study, which encode for proteins with similarity to a putative general stress protein (GspM) harboring GsiB domain and a putative enoyl-

\section{Springer Open}

๑ The Author(s). 2020 Open Access This article is licensed under a Creative Commons Attribution 4.0 International License, which permits use, sharing, adaptation, distribution and reproduction in any medium or format, as long as you give appropriate credit to the original author(s) and the source, provide a link to the Creative Commons licence, and indicate if changes were made. The images or other third party material in this article are included in the article's Creative Commons licence, unless indicated otherwise in a credit line to the material. If material is not included in the article's Creative Commons licence and your intended use is not permitted by statutory regulation or exceeds the permitted use, you will need to obtain permission directly from the copyright holder. To view a copy of this licence, visit http://creativecommons.org/licenses/by/4.0/. 
CoA hydratase (EchM) [7]. To enhance salt tolerance in higher plants, numerous genes have been cloned, e.g., gene encoding late embryogenesis abundant proteins (HVA) [8], P5CS [9], DREB1A [10], and AtNHX1 [11]. Alfin1 (a putative transcription factor) and HAL1 (from yeast) have been engineered in alfalfa and tomato plants, respectively, to obtain salt-tolerant plants [12]. HAL1 alters the salt tolerance of tomato and increases the $\mathrm{K}^{+}$/ $\mathrm{Na}^{+}$ratio in transgenic plants. Another choline oxidase gene from Arthrobacter globiformis has been transferred to Arabidopsis thaliana to enhance their salt tolerance [13]. The overexpression of fusion genes, OsDST-SRDX [14] and AmRosea1 [15], significantly improved the salt tolerance of transgenic perennial ryegrass and rice, respectively. The isolation and identification of new salinity stress-induced genes will be useful in developing crop plants resistant to salinity stress. Previously, we reported the molecular characterization and halozyme production from halophiles of Lunsu salt water body of Northwestern Himalayas [16, 17]. In the present study, the strict halophile Halobacillus trueperi SS1 was explored for the genes conferring salt tolerance by selective screening of its genomic library.

\section{Methods}

\section{Bacterial strain and genomic DNA isolation}

Genomic DNA of Halobacillus trueperi SS1 (Genbank Accession no. KM260166) was isolated as described [16]. Halobacillus trueperi SS1 was isolated from Lunsu soil sample as described [16]. H. trueperi SS1 is a strict halophile and exhibits growth up to $4.5 \mathrm{M} \mathrm{NaCl}$ with the optimal growth at $2 \mathrm{M} \mathrm{NaCl}$.

\section{Genomic library construction}

Plasmid DNA isolation, restriction enzyme digestion, ligation, and competent cell preparation were carried out by standard procedures [18]. Ten micrograms of $H$. trueperi SS1 genomic DNA was partially digested with BamH1, and DNA fragments in the range of $1-6 \mathrm{~kb}$ were excised from agarose gel $(0.8 \%)$ using gel extraction kit (Fermentas Inc. USA). Two hundred nanograms of partially digested DNA was ligated to BamHI digested pUC19 vector by using T4 DNA ligase. The ligated product was transformed into $E$. coli $\mathrm{DH} 5 \alpha$ competent cells, and transformants were plated on LB agar plates containing ampicillin $(100 \mu \mathrm{g} / \mathrm{ml})$ and X-Gal/IPTG for blue-white selection.

\section{Screening of recombinant genomic clones of $H$. trueperi SS1 for salt tolerance}

For screening of salt tolerance gene(s), E. coli transformants harboring genomic DNA clones of $H$. trueperi SS1 genes in pUC19 were plated on LB ampicillin media containing $0.75 \mathrm{M} \mathrm{NaCl}$. Such a selection allowed the growth of only those $E$. coli transformants that contain gene(s) for salt tolerance. The transformants that showed growth in the presence of $\mathrm{NaCl}$ were selected and used for the isolation of plasmid by alkaline lysis [18]. The plasmid DNA was analyzed by restriction digestion for the release of insert.

\section{Functional characterization of genomic clones of $\mathrm{H}$. trueperi SS1 conferring salt tolerance to $E$. coli/DH5a} The growth pattern of the genomic clone of $H$. trueperi SS1 was studied in the LB agar medium and LB agar medium supplemented with ampicillin and different concentrations of $\mathrm{NaCl}(0.5,0.75,1,1.2$, and 1.5 $\mathrm{M})$. The E. coli/DH5 $\alpha$ harboring genomic clone and control E. coli/pUC19 were cultured in the LB medium supplemented with ampicillin, while E. coli/ $\mathrm{DH} 5 \alpha$ in LB alone, by incubating at $37^{\circ} \mathrm{C}$ for $24 \mathrm{~h}$ with shaking at $200 \mathrm{rpm}$. The absorbance of the culture was measured at $600 \mathrm{~nm}$, and cell density was normalized to $A_{600}=1$. Serial dilutions of equal number of cells of each strain were spotted on different media as described, and the plates were incubated at $37^{\circ} \mathrm{C}$ for $24 \mathrm{~h}$.

The salt tolerance of the genomic clone was further analyzed by liquid growth assay in the LB medium supplemented with ampicillin and different concentrations of $\mathrm{NaCl}(0,0.75$, and $1.0 \mathrm{M} \mathrm{NaCl})$. Incubation was done at $37^{\circ} \mathrm{C}$ for $24 \mathrm{~h}$ with shaking at $200 \mathrm{rpm}$. The absorbance of the culture was measured at $600 \mathrm{~nm}$ at various time intervals and the growth curve was plotted.

\section{Confirmation of recombinant genomic clone}

The plasmid DNA of salt-tolerant clone (STC) was used as a template for PCR amplification by using pUC19specific primers (pUC19 F 5' GTAAAACGACGGCC AGT 3' and pUC19 R 5' CAGGAAACAGCTATGAC $\left.3^{\prime}\right)$. PCR mixture was prepared by mixing the components $(1 \mu \mathrm{M}$ of each primer, $0.2 \mathrm{mM}$ each of dNTPs, $100 \mathrm{ng}$ of plasmid DNA, and $1 \mathrm{U}$ of Taq DNA polymerase). The reaction mixture tubes were subjected for thermal cycling reaction of initial denaturation at $94^{\circ} \mathrm{C}$ for 2 min, followed by 35 cycles of denaturation $\left(94{ }^{\circ} \mathrm{C}, 30 \mathrm{~s}\right)$, annealing $\left(40^{\circ} \mathrm{C}, 30 \mathrm{~s}\right)$, and extension $\left(72{ }^{\circ} \mathrm{C}, 2 \mathrm{~min}\right)$, with a final extension of $10 \mathrm{~min}$ at $72{ }^{\circ} \mathrm{C}$. The results were analyzed using $1.2 \%$ agarose gel and stained with ethidium bromide and visualized with an UV gel documentation system.

For verification of the recombinant clone for salt tolerance traits, it was subcloned into pGEX4T2 expression vector by using appropriate restriction enzymes and analyzed for salt tolerance. 
Identification of genes conferring salt tolerance in the recombinant genomic clone

The gene conferring salt tolerance was subjected to DNA sequencing on both strands using pUC19-specific forward and reverse primers. The plasmid DNA sequencing was carried out at Eurofins-Operon Pvt Ltd, Bangalore, India. DNA sequence was assembled and translated to amino acid sequence using Expasy tools. The Translate tool namely ExPASy Protein BLAST was used for multiple alignment of sequence, and the open reading frame (ORF) was predicted using an ORF finder tool at NCBI (http://www.ncbi.nlm.nih.gov/gorf/gorf. html) and analyzed for the database homology with BLAST (http://www.ncbi.nlm.nih.gov/blast).

\section{Results and discussion}

Isolation of gene(s) conferring salt tolerance from $\mathrm{H}$. trueperi SS1

Owing to the ability of halophilic isolate $H$. trueperi SS1 to survive in hyper-saline conditions $(4.5 \mathrm{M} \mathrm{NaCl})$, it was used to isolate potential salt tolerance genes. Since there is limited information on the genome of extremophiles like $H$. trueperi, the study was carried out to generate a genomic library and used to screen for genes/ gene clusters for salt tolerance. To isolate genes conferring salt tolerance, a genomic library was constructed from BamH1 digested H. trueperi SS1 DNA. For the construction of the genomic library of $H$. trueperi SS1, pUC19 cloning vector was selected owing to its potential of blue/white recombinant screening. Blue/white screening identified $>200$ white colonies. All the recombinant clones were screened for salt $(\mathrm{NaCl})$ tolerance in a growth medium supplemented with $0.75 \mathrm{M} \mathrm{NaCl}$ and ampicillin. A recombinant clone designated as salttolerant clone (STC) showed growth on the medium supplemented with $0.75 \mathrm{M} \mathrm{NaCl}$ and ampicillin, after incubation at $37^{\circ} \mathrm{C}$ for $24 \mathrm{~h}$, indicating salt-tolerant nature of the transformant (Fig. 1).

The isolation of salt-tolerant clones has been reported from pond water metagenome which showed growth in the medium containing $750 \mathrm{mM} \mathrm{NaCl}$, in comparison to E. coli/pUC19 [7].

Similarly, Ahmed et al. [19] reported recombinant plasmids named as pSSR1, pSSR4, pSSR6, and pSSR21, which showed significant growth in the presence of $\mathrm{NaCl}[4.0 \%(\mathrm{w} / \mathrm{v})]$ and $\mathrm{KCl}[5.5 \%(\mathrm{w} / \mathrm{v})]$ as compared to E. coli (DH10B) strain carrying empty plasmid vector (pUC19) [19].

Characteristics of salt tolerance of recombinant clone STC The growth of recombinant clone STC was checked by spotting assay on the LB agar medium containing 0.5 , $0.75,1.0,1.2$, and $1.5 \mathrm{M} \mathrm{NaCl}$ (Fig. 1a-f) and the LB agar medium supplemented with ampicillin and different concentrations of $\mathrm{NaCl}(0-1.5 \mathrm{M})$ (Fig. 1g-l). Interestingly, recombinant clone STC showed detectable growth up to $1.2 \mathrm{M} \mathrm{NaCl}$, where as host strain $E$. coli DH5 $\alpha$ and DH5 $\alpha$ transformed with pUC19 (vector alone) did not show any growth above $0.5 \mathrm{M} \mathrm{NaCl}$. These results clearly support the fact that $\mathrm{NaCl}$ tolerance is an intrinsic property and STC clone might possess gene(s) that confer salt tolerance to $E$. coli strain DH5 $\alpha$.

In another study, the RelA/SpoT homolog Sj-RSH was isolated from Suaeda japonica cDNA library [20]. The $\mathrm{Sj}$-RSH transformant grew in the presence of $0.4 \mathrm{M}$ $\mathrm{NaCl}$ as compared to other transformants, which showed growth in the presence of $0.086 \mathrm{M} \mathrm{NaCl}$. It was concluded that gene encoding $\mathrm{Sj}$-RSH might play an important role in the salt- and osmotic-stress tolerance conferred to E. coli [20]. On the other hand, the STC clone, isolated in the present study, conferred salt tolerance up to $1.2 \mathrm{M} \mathrm{NaCl}$.

The salt tolerance of DH $5 \alpha /$ STC was characterized by analysis of the growth kinetics in liquid media as follows: LB medium (Fig. 2a), LB medium supplemented with ampicillin $(100 \mu \mathrm{g} / \mathrm{ml})$ and $0.75 \mathrm{M} \mathrm{NaCl}$ (Fig. 2b), and LB medium supplemented with ampicillin $(100 \mu \mathrm{g} / \mathrm{ml})$ and $1 \mathrm{M} \mathrm{NaCl}$ (Fig. 2c). The recombinant strain E. coli/ STC exhibited a hyperbolic growth pattern and achieved maximum growth in $24-28 \mathrm{~h}$ in the medium containing 0.75 and $1 \mathrm{M} \mathrm{NaCl}$ (Fig. 2b, c). On the other hand, the control E. coli/pUC19 and E. coli/DH5 $\alpha$ did not show any significant growth in the presence of salt (Fig. 2b, c). These results reinforce the fact that the STC clone confers salt tolerance to the E. coli strain harboring the recombinant clone.

\section{Verification of the STC clone}

To verify and determine the size of the insert in the STC, the recombinant plasmid DNA of the STC clone was digested with $\mathrm{BamH1}$. BamH1 digestion released a DNA fragment of $\sim 2 \mathrm{~kb}$ (Supplementary Fig S1a), indicating the presence of an insert $\sim 2 \mathrm{~kb}$. The presence of the insert was also confirmed by PCR analysis using pUC19 primers flanking the MCS. An amplicon of $\sim 2$ $\mathrm{kb}$ was amplified from STC, which confirms restriction analysis (Supplementary Fig S1b).

\section{Identification of STC}

To identify the genes present in the insert in STC, the insert was sequenced on both strands of DNA. A nucleotide sequence of 2301 bp was obtained (Supplementary Fig S2) and analyzed by BLAST. The DNA sequence was translated into six frames by using Expasy tool, and each frame was subjected to protein BLAST (Table 1).

Out of the six open reading frames (ORFs), two frames gave the highest identity (97 and $94 \%$, respectively) with Putative multidrug export ATP binding/permease 
a

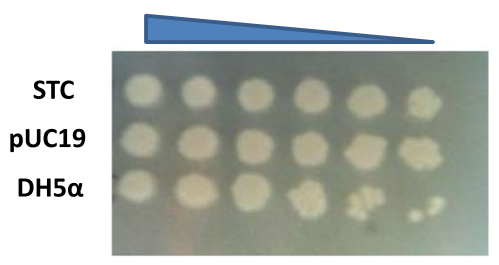

C

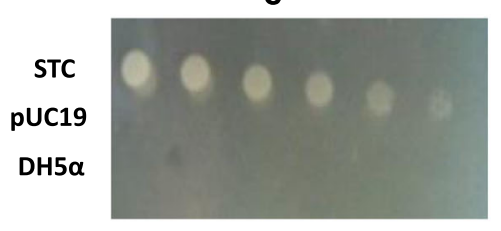

e

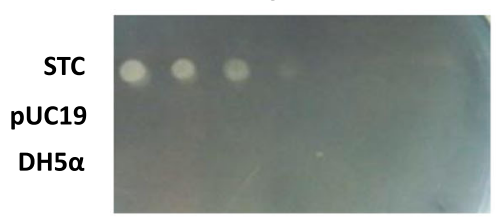

g

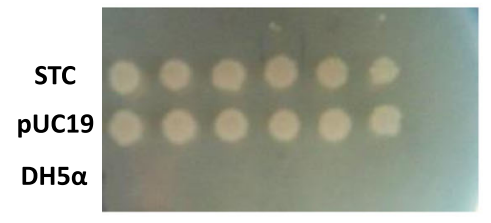

i

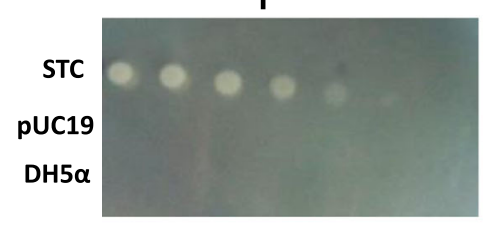

k

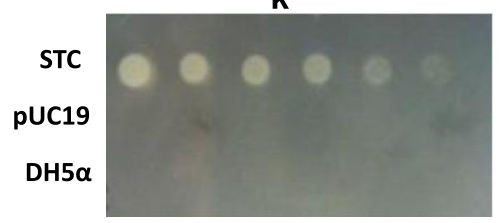

b

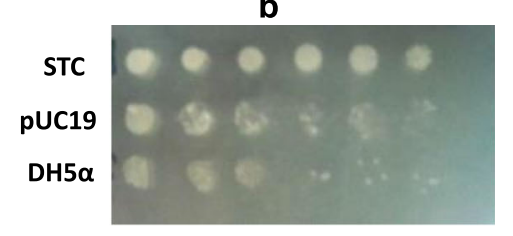

d

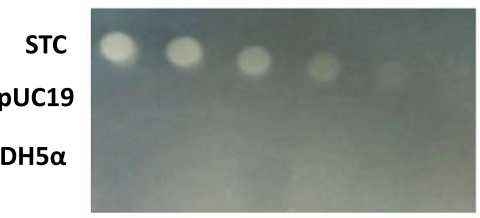

f

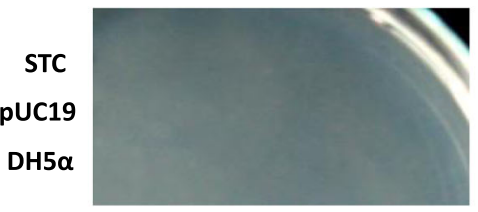

h

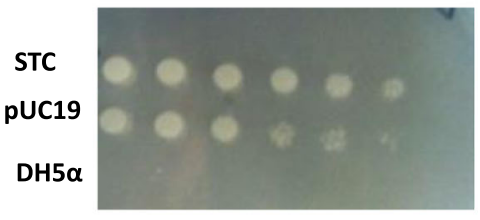

j

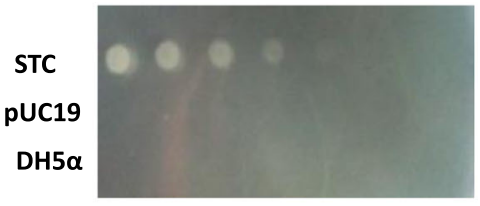

I

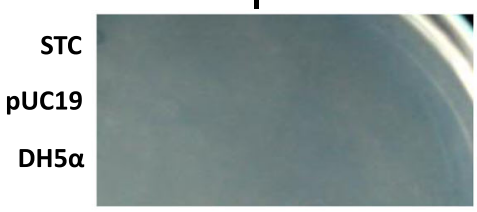

Fig. 1 Growth characteristics of recombinant clone STC. The growth of recombinant clone STC, DH5a transformed with pUC19, and DH5a host strain were analyzed for $\mathrm{NaCl}$ tolerance in the LB agar medium. A tenfold serial dilution (from left to right as indicated above panel a) of each strain was spotted on the LB medium (a-f) and LB medium containing ampicillin ( $\mathbf{g}-\mathbf{I})$ and increasing concentration of $\mathrm{NaCl}$ as follows: 0 (a, $\mathbf{g}$ ), $0.5(\mathbf{b}, \mathbf{h}), 0.75(\mathbf{c}, \mathbf{i}), 1.0(\mathbf{d}, \mathbf{j}), 1.2(\mathbf{e}, \mathbf{k})$ and $1.5 \mathrm{M}(\mathbf{f}, \mathbf{l})$. The medium without $\mathrm{NaCl}$ was used as control

protein, and the third frame gave $90 \%$ identity with putative membrane protein from Halobacillus sp. (Table 1). The ATP-binding cassette transporters (ABC transporters) are a transport system superfamily. These genes encode integral membrane proteins that translocate a wide range of solutes across membranes [21]. ABC proteins can act as importers, exporters, receptors, and channels. $\mathrm{ABC}$ uptake porters take up a large variety of nutrients, biosynthetic precursors, trace metals, and vitamins, while exporters transport lipids, sterols, drugs, and a large variety of primary and secondary metabolites [22].

Ahmed et al. [19] reported a putative branched-chain amino acid (BCAA) ABC transporter gene (BCAA_ABCTP) (putative $B C A A \_A B C T P$ ) gene, which was subcloned (pSSR1C1) in salt-sensitive E. coli strain MKH13. The transformed strain bearing $p S S R 1 C 1$ showed a significant growth in the presence of $\mathrm{NaCl}[3.0 \%(\mathrm{w} / \mathrm{v})]$ and $\mathrm{KCl}[3.7 \%(\mathrm{w} / \mathrm{v})]$ as compared to the strain carrying only the empty vector 
a

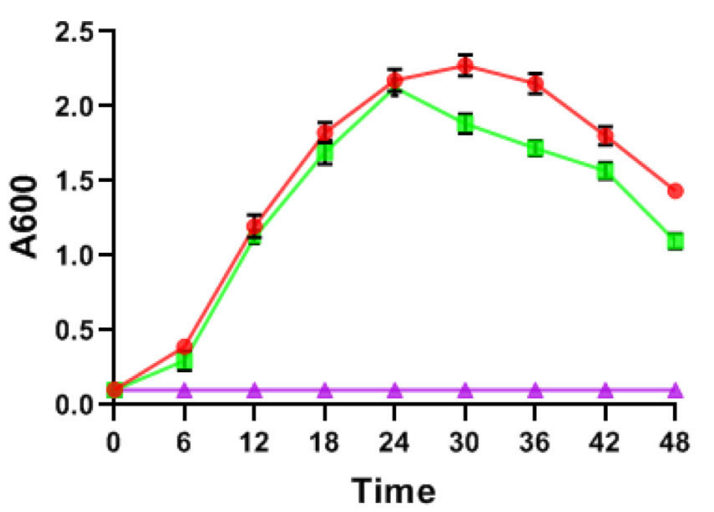

b

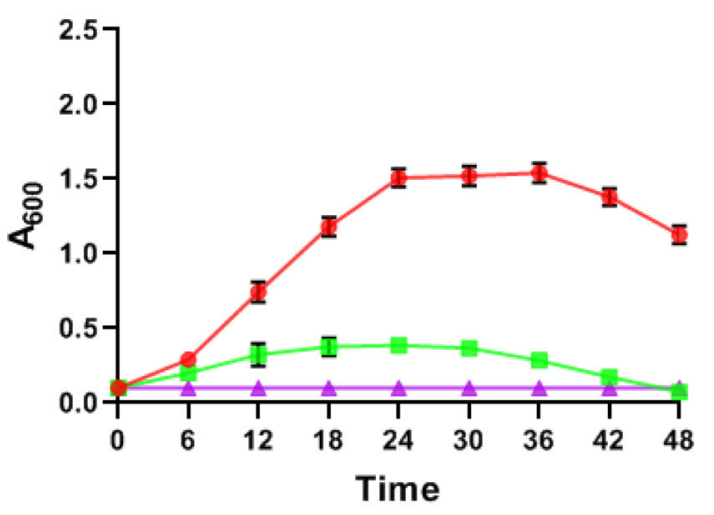

C

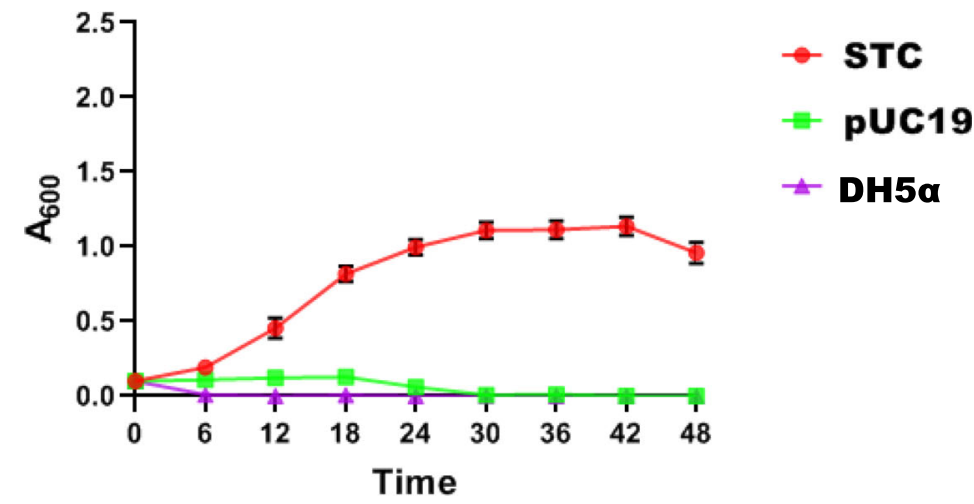

Fig. 2 Growth kinetics of recombinant clone STC. Panel a represents control with ampicillin and without added salt; panels $\mathbf{b}$ and $\mathbf{c}$ represent salinity treatment with $0.75 \mathrm{M} \mathrm{NaCl}$ and $1 \mathrm{M} \mathrm{NaCl}$, respectively, in the presence of ampicillin. Recombinant clone STC (red line) in DH5a, DH5a containing pUC19 (green line), and DH5a host strain (violet line) were inoculated in the LB medium supplemented with ampicillin (a), LB medium supplemented with ampicillin and $0.75 \mathrm{M} \mathrm{NaCl}$ (b), and LB medium supplemented with ampicillin and $1 \mathrm{M} \mathrm{NaCl}$ (c). Cells were withdrawn at different intervals, and absorbance was measured at $600 \mathrm{~nm}$. Data of three independent experiments was plotted with standard deviation

(pUC19) [19]. In another study, a metagenomic library from the human gut microbiota was screened for potential salttolerant clones [23]. Transformed clones showed a significant increase in salt tolerance $(0.5 \mathrm{M} \mathrm{NaCl})$ compared with the wild-type E. coli strain MKH13. Five genes were identified in the clone namely galE (3), galE (25), mazG (3), mazG (5), and murB (3) [23].
Verification of salt tolerance trait of the STC by retransformation

To further confirm the presence of the salt tolerance gene in the 2-kb insert of STC, the insert was released and subcloned into pGEX 4T2 vector. The vector pGEX4T2 was selected towards subcloning and reconfirmation of salt tolerance of the genomic insert of the 
Table 1 Protein BLAST analysis of the H. trueperi SS1 genomic DNA insert present in STC. The predicted ORFS and their BLAST hits are indicated

\begin{tabular}{|c|c|c|c|c|c|}
\hline \multirow{2}{*}{$\begin{array}{l}\text { Clone } \\
\text { STC }\end{array}$} & \multirow{2}{*}{$\begin{array}{l}\text { Open } \\
\text { reading } \\
\text { frame (ORF) }\end{array}$} & \multicolumn{4}{|l|}{ Best match } \\
\hline & & Protein name accession number & $\begin{array}{l}\text { Size } \\
\text { aa }\end{array}$ & Organism & Identity \\
\hline \multirow{6}{*}{$\begin{array}{l}\text { Insert } \\
\text { size } \\
2301 \mathrm{bp}\end{array}$} & 3'-5' FRAME 3 & $\begin{array}{l}\text { Putative multidrug export ATP binding/permease } \\
\text { protein }\end{array}$ & 101 & $\begin{array}{l}\text { Halobacillus karajensis GN=BN983 } \\
02429\end{array}$ & $95 / 98=97 \%$ \\
\hline & 3'-5' FRAME 2 & $\begin{array}{l}\text { Putative multidrug export ATP binding/permease } \\
\text { protein }\end{array}$ & 153 & $\begin{array}{l}\text { Halobacillus karajensis GN=BN983 } \\
\text { _02429 }\end{array}$ & $134 / 143=94 \%$ \\
\hline & 5'-3' FRAME 2 & Putative membrane protein & 165 & $\begin{array}{l}\text { Halobacillus karajensis } \mathrm{GN}=\mathrm{BN} 983 \\
\text { _02430 }\end{array}$ & $148 / 165=90 \%$ \\
\hline & 3'-5' FRAME 1 & Multidrug ABC transporter ATP binding protein OS & 99 & Halobacillus sp. BBL2006 & $23 / 34=64 \%$ \\
\hline & 5'-3' FRAME 3 & Membrane protein & 49 & Aquimarina sp. GN=AT012_12720 & $13 / 39=33 \%$ \\
\hline & 5'-3' FRAME 1 & Glycosyl transferase family & 29 & $\begin{array}{l}\text { Geobacter lovleyi } \\
\text { ATCC BAA-1151 }\end{array}$ & $16 / 55=29 \%$ \\
\hline
\end{tabular}

STC clone. The transformants were checked for growth on media supplemented with $\mathrm{NaCl}(0-1.5 \mathrm{M})$. The transformants containing pGEX4T2/STC grew on the media supplemented with ampicillin and 0-1.0 M NaCl (Supplementary Fig S3a-j), while the control strain containing pGEX4T2 vector failed to grow on the media supplemented with $0.75 \mathrm{M} \mathrm{NaCl}$ (Supplementary Fig S3). These results indicate the plasmid-borne nature of salt tolerance (pGEX4T2/STC). Restriction digestion of the clone pGEX4T2/STC revealed that it contained an insert of $2.0 \mathrm{~kb}$ (data not shown).

Similarly, Agrobacteium tumifaciens strain LBA 4404 was transformed with the gene encoding choline oxidase [24]. The transformants were able to survive in the presence of $0.3 \mathrm{M} \mathrm{NaCl}$. Deshnium et al. [24] also observed increased salinity tolerance up to $0.4 \mathrm{M} \mathrm{NaCl}$ in Synechococus sp. when transformed with $\operatorname{cod} A$ gene encoding choline oxidase.

In the present study, the E. coli strain DH5 $\alpha$ by itself exhibited growth in the presence of $0.5 \mathrm{M} \mathrm{NaCl}$. Accordingly, the $\mathrm{Sj}-\mathrm{RSH}$ clone identified by Yamada et al. [20] might not qualify to be $a$ salt tolerance clone. The comparison of salt tolerance of STC isolated in this study with those reported in literature reveals that STC confers the highest salt tolerance (up to $1.2 \mathrm{M} \mathrm{NaCl}$ ) to its host strain (E. coli) amongst all the salt-tolerant genes reported so far.

Sequencing of the genomic DNA insert of $H$. trueperi SS1 in STC indicated the presence of gene homologous to putative multidrug export ATP binding/permease of Halobacillus karajensis (Table 1). Consistent with these results, genome sequencing of Halobacillus trueperi SS1 revealed the presence of permeases/transporters [25]. Further analysis of the genome sequence will shed light into the mapping of the salt tolerance gene isolated in this study. Studies on the mechanism of salt tolerance in $H$. trueperi SS1 showed that the strict halophile utilizes a combination of salt-in strategy and accumulation of compatible solutes to combat salt stress [26]. Since both strategies require transport proteins, the putative permease homolog of Halobacillus karajensis identified in the STC clone might be involved in $\mathrm{Na}^{+}$and $\mathrm{K}^{+}$transport or in the accumulation of organic osmolytes (proline, glycine, sugars, or alcohols) to confer salt-tolerant growth to native Halobacillus trueperi SS1 and to the transformed $E$. coli host.

\section{Conclusion}

The present study led to the isolation of gene conferring salt tolerance (up to $1.2 \mathrm{M} \mathrm{NaCl}$ ) from the genomic library of $H$. trueperi SS1. Further studies on cloning and biochemical characterization of the putative permease of $H$. trueperi SS1 will shed light into the mechanism of salt tolerance. The salt tolerance gene (putative multidrug export ATP binding/permease protein) isolated from $H$. trueperi SS1 can serve as a tool for engineering salt tolerance in agricultural crop plants like rice, the major crop grown in coastal regions suffering salinity stress.

\section{Supplementary information}

Supplementary information accompanies this paper at https://doi.org/10. 1186/s43141-020-00070-6.

Additional file 1: Figure S1. Restriction digestion and PCR analysis of STC clone. (a) Restriction digestion of pUC19 (vector) and STC (recombinant clone) with BamH1. Lane1. pUC19 plasmid DNA; lane 2, pUC19 plasmid DNA digested with BamH1; Lane 3, plasmid DNA of clone STC and lane 4, plasmid DNA of STC digested with BamH1. (b) PCR analysis of STC with pUC19 primers flanking multiple cloning site. Lane 1, PCR amplified product of pUC19; and Lane 2, PCR amplified product of clone STC. Lane M indicates the DNA molecular size marker (kb). The release of an insert of $\sim 2 \mathrm{~kb}$ and its specific PCR amplification are indicated. Figure S2. Nucleotide sequence of $H$. trueperi SS1 genomic DNA insert in STC clone corresponding to $2301 \mathrm{bp}$. The insert was sequenced on both strands using pUC19 primers. The two sequences were aligned and overlaps were removed to assemble the sequence of 2301 bp. Figure S3. Growth characteristics of STC subcloned in 
pGEX4T2. The growth of recombinant clone STC, control DH5a transformed with pGEX4T2 and DH5a host strain were analyzed for $\mathrm{NaCl}$ tolerance in LB agar medium. A ten fold serial dilution (from left to right as indicated above panel a) of each strain was spotted on LB medium (a - e) and LB medium containing ampicillin ( $f-j)$ and increasing concentration of $\mathrm{NaCl}$ as follows: 0 (a and f), 0.5 ( $b$ and g), 0.75 (c and h), $1.0(\mathrm{~d}$ and $\mathrm{i})$ and $1.5 \mathrm{M}$ (e and $\mathrm{j})$.

\section{Abbreviations}

BLAST: Basic local alignment search tool; DNA: Deoxyribonucleic acid; $E$. coli: Escherichia coli; IPTG: Isopropyl $\beta$-D-1-thiogalactopyranoside; LB: LuriaBertani; MCS: Multiple cloning site; NaCl: Sodium chloride; UV: Ultraviolet; Xgal: 5-Bromo-4-chloro-3-indolyl- $\beta$-D-galactopyranoside

\section{Acknowledgements}

The authors would like to deeply acknowledge Vice Chancellor, Shoolini University, Bajhol, Solan, Himachal Pradesh, India, for providing inspiration and infrastructural support for this study and all the members of Yeast Biology Lab for support.

\section{Authors' contributions}

SG and PS performed the experiments and drafted the manuscript; KD and AS conceived the study and participated in its design and coordination and helped to finalize the manuscript. The authors read and approved the final manuscript.

\section{Funding}

No funding was received for this study. Shoolini University, Solan, HP, India, provided infrastructural and consumables support for the study.

\section{Availability of data and materials}

Additional data is provided as supplementary material.

\section{Ethics approval and consent to participate}

Not applicable.

\section{Consent for publication}

Not applicable.

\section{Competing interests}

The authors declare that they have no competing interests.

Received: 5 May 2020 Accepted: 8 September 2020

Published online: 06 October 2020

\section{References}

1. Flowers TJ, Yeo AR (1995) Breeding for salinity resistance in crop plants-where next? Aust J Plant Physiol 22:875-884

2. Flowers TJ (2004) Improving crop salt tolerance. J Exp Bot 55:307-319

3. Zuleta LFG, Italiani VCS, Marques MV (2003) Isolation and characterization of $\mathrm{NaCl}$-sensitive mutants of Caulobacter crescentus. Appl Environ Microbiol 69: 3029-3035

4. Naughton LM, Blumerman SL, Carlberg M, Boyd EF (2009) Osmoadaptation among Vibrio species and unique genomic features and physiological responses of Vibrio parahaemolyticus. Appl Environ Microbiol 75:2802-2810

5. Kapley A, Purohit HJ, Chhatre S, Shanker R, Chakrabarti T, Khanna P (1999) Osmotolerance and hydrocarbon degradation by a genetically engineered microbial consortium. Bioresour Technol 67:241-245

6. Klahn S, Marquardt DM, Rollwitz I, Hagemann M (2009) Expression of the ggpPS gene for glucosylglycerol biosynthesis from Azotobacter vinelandil improves the salt tolerance of Arabidopsis thaliana. J Exp Bot 60:1679-1689

7. Kapardar RK, Ranjan R, Grover A, Puri M, Sharma R (2010) Identification and characterization of genes conferring salt tolerance to Escherichia coli from pond water metagenome. Bioresour Technol 101:3917-3924

8. Xu D, Duan X, Wang B, Hong B, Ho HD, Wu R (1996) Expression of a late embryogenesis abundant protein gene, HVA1, from barley confers tolerance to water deficit and salt stress in transgenic rice. Plant Physiol 110:249-257

9. Kishor PB, Hong Z, Miao G, Hu CA, Verma DPS (1995) Overexpression of Dpirroline-5-carboxylate synthetase increases proline production and confers osmotolerance in transgenic plants. Plant Physiol 108:1387-1394
10. Kasuga M, Liu Q, Miuras S, Yamaguchi-Shinozaki K, Shinozaki K (1999) Improving plant drought, salt and freezing tolerance by gene transfer of a single stress-inducible transcription factor. Nat Biotechnol 17:287-291

11. Apse MP, Aharon GS, Snedden WA, Blumwald E (1999) Salt tolerance conferred by overexpression of a vacuolar $\mathrm{Na}+/ \mathrm{H}+$ antiport in Arabidopsis. Sci 285:1256-1258

12. Gisbert C, Ana M, Rus AM, Carmen Bolarín MC, López-Coronado JM, Arrillaga I, Manuel Caro M, Serrano R, Moreno V (2000) The yeast HAL1 gene improves salt tolerance of transgenic tomato. Plant Physiol 123(1):393-402

13. Empadinhas N, da Costa MS (2008) Osmoadaptation mechanisms in prokaryotes: distribution of compatible solutes. Int Microbiol 11:151-161

14. Cen H, Ye W, Liu Y, Li D, Wang K, Zhang W (2016) Overexpression of a chimeric gene, OSDST-SRDX, improved salt tolerance of perennial ryegrass. Sci Rep 6:27320. https://doi.org/10.1038/srep27320

15. Dou M, Fan S, Yang S, Huang R, Yu H, Feng X (2017) Overexpression of AmRosea1 gene confers drought and salt tolerance in rice. Int J Mol Sci 18(1):2. https://doi.org/10.3390/ijms18010002

16. Gupta S, Sharma P, Dev K, Srivastava M, Sourirajan A (2015) A diverse group of halophilic bacteria exist in Lunsu, a natural salt water body of Himachal Pradesh, India. Springer Plus 4:274. https://doi.org/10.1186/s40064-015-1028-1

17. Gupta S, Sharma P, Dev K, Sourirajan A (2016) Halophilic bacteria of Lunsu produce an array of industrially important enzymes with salt-tolerant activity. Biochem Res Int 9237418:10. https://doi.org/10.1155/2016/9237418

18. Sambrook J, Fritsch EF, Maniatis T (2009) Molecular cloning: a laboratory manual by Joe Sambrook Third Edition. Cold Spring Harbor Laboratory Press

19. Ahmed V, Manoj K, Verma MK, Gupta S, Mandhan V, Chauhan N (2018) Metagenomic profiling of soil microbes to mine salt stress tolerance genes. Front Microbiol. https://doi.org/10.3389/fmicb.2018.00159

20. Yamada A, Tsutsumi K, Tanimoto S, Ozeki Y (2003) Plant RelA/SpoT homolog 375 confers salt tolerance in Escherichia coli and Saccharomyces cerevisiae. Plant Cell 44(1):3-9

21. Young J, Holland IB (1999) ABC transporters: bacterial exporters-revisited five years on. Biochim Biophys Acta Biomembr 1461:177-200

22. Higgins CF (1992) ABC Transporters: from microorganisms to man. Annu Rev Cell Dev Biol 8:67-113

23. Culligan EP, Sleator RD, Julian R, Marchesi JR, Hill C (2012) Functional metagenomics reveals novel salt tolerance loci from the human gut microbiome. ISME J 6:1916-1925

24. Deshnium P, Los DA, Hayashi H, Mustardy L, Murata N (1995) Transformation of Synechococcus with a gene for choline oxidase enhances tolerance to salt stress. Plant Mol Biol 29:897-907

25. Gupta S, Sharma P, Dev K, Baumler DJ, Sourirajan A (2019) Draft genome sequence of Halobacillus trueperi SS1 isolated from Lunsu, a salt water body of North West Himalayas. Microbiol 8(10):e01710-e01718. https://doi.org/10. 1128/MRA.01710-18

26. Vaidya S, Dev K, Sourirajan A (2018) Distinct osmoadaptation strategies in the strict halophilic and halotolerant bacteria isolated from Lunsu salt water body of North West Himalayas. Curr Microbiol 75(7):888-895. https://doi. org/10.1007/s00284-018-1462-8

\section{Publisher's Note}

Springer Nature remains neutral with regard to jurisdictional claims in published maps and institutional affiliations.

\section{Submit your manuscript to a SpringerOpen ${ }^{\circ}$ journal and benefit from:}

- Convenient online submission

- Rigorous peer review

- Open access: articles freely available online

- High visibility within the field

- Retaining the copyright to your article

Submit your next manuscript at $>$ springeropen.com 